\title{
EFFECT OF PEER-TUTORING LEARNING TEACHING MEHOD ON ACADEMIC PERFORMANCE OF FINANCIAL ACCOUNTING STUDENTS IN FEDERAL UNITY COLLEGES, IN NORTH-EASTERN NIGERIA
}

\author{
DR ADAMU IBRAHIM ${ }^{1}$, KUSA GIPSON WUNBA ${ }^{2}$ \\ 1,2 DEPARTMENT OF VOCATIONAL AND TECHNOLOGY EDUCATION FACULTY OF \\ EDUCATION ABUBAKAR TAFAWA BALEWA UNIVERSITY, BAUCHI.
}

\section{ARTICLE INFO}

Keywords:

Accounting, Learning,

Peer-Tutoring,

Performance

\begin{abstract}
This study established the effect of peer tutoring teaching method on students' performance in financial accounting in Federal unity Colleges of in North-East, Nigeria. The study had three objectives, three research questions and three null hypotheses. Quasi experimental design was used for the study. The population of the study was 130 SS II Financial Accounting students. An intact two classes of 46 students were used for the study. Two instruments were used for data collection were validated by four experts. The instrument had the coefficient of 0.87 and 0.89 . The difficulty index of instruments stood at 0.76 and 0.81 . The discriminating index of the items range from 0.5 to 0.7 . Data collected were analyzed using mean and mean difference to answer the research questions. T-test was employed in testing the hypotheses at 0.05 level of significance. The findings revealed among others that there was significant difference between the mean performance of financial accounting students in experimental group and those in control group. It was concluded that using of peer tutoring strategy will help to improve the performance of financial accounting students. It was recommended among others that, accounting teachers should develop habit of using interactive methods which allows students to actively participate in the teaching and learning excise.
\end{abstract}

\section{Introduction}

An organization no matter small is it a profit making, a charitable or even a home deals with money finds financial accounting very useful. In Nigeria, financial accounting is one of the commercial subjects at secondary school level. The philosophy of the subject is to further provide students with skills and knowledge of what was taught at basic 9 educational level and also provide the teacher with the framework within which the teaching is to take place. Generally, financial accounting aims at providing specialized instruction to prepare students for career in financial accounting field. According to National Examination Council (NECO, 2004), the objective of studying financial accounting in senior secondary schools is to enable students appreciate basic 
rules, lay proper foundation and understand basic accounting principle and practice and their application in modern business activities.

According to Jibrin, Ibrahim and Zayum (2016), the most appropriate pedagogical approaches is that promotes students' academic performance. The study of Ishaq (2011) and Tran (2014) revealed that almost all the traditional teaching approaches used in schools around the world include lectures and demonstration which have negative effect on learning outcome of the students. Nura (2008) and Joseph and Joel (2015) argued that teachers centred methods (lectures and demonstration) are not appropriate for skills subjects. Based on this, some teaching methods and strategies have been proved to be efficacious in the teaching and learning of abstract and difficult concepts in different skills subjects than the conventional method. To this end, literature revealed the effectiveness of peer-tutoring method. For example, The assertions of researchers such Adamu, Haruna \& Bashir (2013), Adamu, Bashir \& Haruna (2015) and Adamu, Haruna \& Bashir (2013), indicates that despite the shortcomings of interactive methods of time consuming, it helps to improve the academic performance and retention ability of students.

Peer-tutoring otherwise known as peer mentoring or peer assisted learning strategy is an effective and affordable way of providing students with academic and personal support from other students (Jibrin, Ibrahim \& Zayum, 2016). In peer-tutoring technique, a higher performing student is paired with a lower one to review critical academic or behavioural concepts. Peer mentoring improves the learning experiences of both the tutors and tutees. When peer tutors participate in these schemes, they not only improve their own understanding of the subject areas, they also develop important communication and teamwork skills. Peer-assisted learning also provides a more comfortable learning environment to allow students to feel at ease and be more focused on the content, which leads to overall better performance in class. Consequently it has been argued that peer-tutoring learning strategy improves the academic achievement of students. The study of Anao (2009) and Sam (2016) shows that through the use of peer-tutoring learning strategies, the knowledge of business mathematics students and biology students improves. Considering the effectiveness of the method, the researchers investigated the effects of peer torturing learning strategies on performance of financial accounting students in federal unity colleges in north-east Nigeria.

Statement of the Problem

The performance of secondary school students in financial accounting has become a major concern. Report form West African Examination Council (2015) shows that 80.5\% of students that sat for accounting examination failed the subject. Similarly, the report of National Examination Council (2013-2016) revealed that the performances of financial accounting students in Senior Secondary is dropping over the years by $55 \%, 40 \%, 33 \%$, and $25 \%$, respectively. As a result of the situation, most students graduate without any saleable skill. The problem is more pronounced with female students. The submission of Ishaq (2011) shows that despite the general poor performance of students, boys out-performed girls in financial accounting at external examination. This was further affirmed by the WASCE chief examiner report (2016) which shows that only $9.8 \%$ female students pass financial accounting at credit level.

In a quest to improve the general performance of students, researchers such as Sahin (2010) and Wael (2014) suggested the used of peer tutoring method. According to Tran (2014) peer tutoring method does not only increase the performance of students, but also promotes their communication abilities and interpersonal relationships. Ani (2007) opined that peer tutoring strategy which is gender friendly helps in enhancing performance and retention ability of students. Based on the forgone submission therefore, the present study intend determine the effectiveness of peer tutoring 
on academic performance of financial accounting students in North-eastern Nigeria. Specifically the study (i) determine the difference between post-test mean achievement of male students that learned financial accounting using peer-tutoring technique and those that adopts conventional technique in federal unity schools in north-eastern Nigeria; (ii) establish the difference between post-test mean achievement of female students that learned financial accounting using peertutoring technique and those that adopts conventional technique in federal unity schools in northeastern Nigeria; and (iii) ascertain the difference between post-test mean achievement of students that learned financial accounting using peer-tutoring technique and those that adopts conventional technique in federal unity schools in north-eastern Nigeria.

\section{Research Question}

The following research questions were raised to guide the study.

1. What is the difference between post-test mean achievement of male students that learned financial accounting using peer-tutoring technique and those that adopts conventional technique in federal unity schools in north-eastern Nigeria?

2. What is the difference between post-test mean achievement of female students that learned financial accounting using peer-tutoring technique and those that adopts conventional technique in federal unity schools in north-eastern Nigeria?

Research Hypothesis

The hypothesis was tested at 0.05 level of significance,

1 There is no significant difference between post-test mean achievement of students that learned financial accounting using peer-tutoring technique and those that adopts conventional technique in federal unity schools in north-eastern Nigeria.

\section{Significance of the Study}

The findings of the study will be of immense benefit to researchers, teachers of financial accounting, Students of financial accounting, curriculum planners, text books authors and school administrators.

The outcome of the study would provide useful information to business educators on what steps to adopt using the peer-tutoring method in teaching-learning process which will help in improving student's performance in financial accounting. Through the research, students who participated in the study will not only improve their own understanding of the subject areas, they also develop important communication and teamwork skills. It will also help in boosting their confidence when they are close to their age bracket and generally helps to feel more relaxed, making them less hesitant to ask questions or clarify an issue

The study would attract the attention of business education curriculum designers to the procedures and strategies to integrate within the framework of the peer-tutoring for developing teacher's guides. In addition, it would also suggest activities to assist in implementing the peer-tutoring strategy successfully. Finally, it is hoped that the study would provide other researchers with some reliable instruments, action procedures, experimental findings and references for employing in future research 


\section{Theoretical Framework}

Instructions methods used by teachers in secondary schools today have remained essentially devoid of practical skills in different trades. The implication is that these schools are graduating students with inadequate or complete lack of practical skills in various trade areas. This portrays a bleak future for the attainment of the lofty goals of the National Policy on Education.. In line with the statement, a teacher cannot foster understanding in a child simply by talking to him or her. He said that "good learning strategy must involve presenting child with situations "in which he/she experiment in the broadest sense of the term "learning through doing." This study adapts the constructivist view of learning by Baumann (2004), who opined that students build their perception on learning, this theory dealt with an active process in which learners construct new ideas or concepts based upon their current/past knowledge. The learner selects and transforms information, constructs hypotheses, and makes decisions, relying on a cognitive structure to do so. Cognitive structure (i.e., schema, mental models) provides meaning and organization to experiences and allows the individual to "go beyond the information given". As far as instruction is concerned, the instructor should try and encourage students to discover principles by themselves. The instructor and student should engage in an active dialog (i.e., socratic learning). The task of the instructor is to translate information to be learned into a format appropriate to the learner's current state of understanding. Curriculum should be organized in a spiral manner so that the student continually builds upon what they have already learned.

Osuala (2013) is of the view that when learners actively take knowledge connects it to previously assimilated knowledge and makes it theirs by constructing their own interpretation. The learning theories are framework describing how information absorbed processed and retained during learning. Cognitive theory influences as well as prior experience all play a part in how understanding and world view is acquired or changed and knowledge, skills retained and explains why the brains is the most incredible network of information processing. Cognitive theory believe that the definition of learning as a change in behaviour is to narrow and prefer to study the learner rather than their environment and in particular complexities of human memory, those who advocate, cognitive describe the information processing model to learning and distinguish the features of multistore of learning, it gives some ideas related to cognitive learning theory covered. The theory is justifying one position over another and select theories that are more viable leading to better theory. It is also educational tutoring systems, Instructional hypermedia design, the justification for this type of system lies in the fact that the learning is a cognitive task and this is in turn to imply theory. While constructivism theories believe that a learner ability to learn relies to a large extent on what he already knows and understands and the acquisition of knowledge should be an individually tailored process of construction. While transformative learning theory focuses upon the necessary change that is required in learners perceptions and world view.

The core objective of education and training is focus on knowledge construction. Curriculum instruction ought to emphasize context and promotes skill development. Therefore educational experiences should be geared towards the individual learner and identity focuses on development of the individual as a member of a community or profession. Teaching and learning activities should be constructed with the learner at the centre. This is in line with constructivism theory of learning that views learning as a process in which the learner actively constructs or builds new ideas or concepts.

\section{Methodology}

The study adopted the non-equivalent pre-test, post- test, control group design. The pre-test, post test suggests that measurements are taken before and after the introduction of the intervention. The 
pre-test helps in examining the differences between the experimental and the control groups' entry behaviour and to establish a baseline for the effect of the treatment. This design enables the researcher to identify and stabilize effects of teaching methods on academic performance of students in Financial Accounting in achieving a goal. Adamu, Bashir and Haruna (2015) opined that a quasi- experimental design merely measures two or more variables rather than manipulating one or more independent variables and subsequently measuring the dependent variable.

The population for the study comprised of all the 258 SSS III Students that offers Financial Accounting in the15 Federal Government Colleges in North-East Zone in 2016/2017 academic session. An intact two class of 46 students from randomly selected schools were used for the study. In order to provide a suitable sampling frame for the study, the multi-stage random sampling technique was adopted using the balloting technique. The two schools selected were randomly assigned into the experimental and control groups. The distribution of the sample is as presented in Table 1.

\begin{tabular}{llll}
\hline S/n & School & Treatment & Students \\
\hline \multicolumn{1}{c}{ 1 Federal Government College, Azare } & Peer-tutoring (Experiment) & 24 \\
2 Federal Government Girls College Bajoga & Conventional (control) & 22 \\
\hline Total & & 46 \\
\hline
\end{tabular}

Two instruments were used for data collection. The first instrument was Accounting Pre-diagnostic Achievement Test (APAT) and the second instrument was Accounting Diagnostic Achievement Test (ADAT). The APAT was a close ended multiple choice questions while the ADAT was open ended exercise that students were required to solve. Despite that the two instruments were adopted from Frank Woods Essential Financial Accounting $4^{\text {th }}$ edition 2012. To further validate the instruments, consultations were made with four accounting lecturers that further established the validity of the instruments.

In order to determine the reliability of the instrument for data collection, test-re-test methods was conducted with 30 students of Federal Government College Kiyawa, Jigawa State which is outside the population of the study and has common characteristics with the studied schools. The result of pilot study gave reliability coefficient of 0.87 for Pre-diagnostic Achievement Test (APAT) while the reliability coefficient of Accounting Diagnostic Achievement Test (ADAT) was 0.89. In this regard, Adamu, Haruna \& Bashir (2013) stated that the average value of correlation co-efficient should not be less than 0.65 . The result of the reliability co-efficient, therefore, indicated that the instrument was reliable. The result of the difficulty index of instruments was 0.76 and 0.81 , which was considered as optimal level. According to the Anowar and Rohani (2013), the Ideal Difficulty of Four-response multiple-choice should be at least 74 should be consider satisfactory for the study. The discriminating index of the items range from 0.5 to 0.7 were obtained, the instrument was also considered satisfactory based on suggestion of Ebel and Frisbie (1986) who opined that discriminating score of $>0.39$ should be considered satisfactory for research work.

Method of Data Collection

The two groups of students were pretested using Accounting Pre-diagnostic Achievement Test (APAT). The scripts of APAT were marked immediately using the drawn marking scheme. In the second stage, the students were exposed to their respective treatment using drawn lesson. The instruction was for 1.20 minutes weekly for the period of four weeks. In the experimental group, the researchers intensively solve one example and assigned two higher achiever financial accounting students who have mastered the content to teach their counterparts. The researchers coaches the tutors how to entertain questions and keep track of their partner's progress before the 
lesson. In order for the lesson to be successful, the researchers support, moderate and monitor the tutoring Sessions.

Students in the control group were personally taught by the researchers using the demonstration teaching strategy. The drawn lesson plans were used as a guide. Both experimental and control groups were taught the same topic (Manufacturing Account, Trading, Profit \& Loss Account and partnership Account). The exercise lasted for seven (7) weeks. At the end of the lesson, Accounting Diagnostic Achievement Test (ADAT) was administered. The scripts of the second instrument were marked using drawn marking schemes. The whole exercises ended in 8 weeks.

The score sheets of ADAT were coded into Statistical Packages of Social Sciences (SPSS) version 21. The package was used to descriptive statistics of mean, standard deviation and mean difference for research question one and two. In the test of the null hypothesis, t-test was employed at 0.05 $\alpha$-level. The benchmark for decision making in respect to research question is presented in Table 3.3 .

Table 3.3: $\quad$ Benchmark for decision making

\begin{tabular}{rlll}
\hline S/No & Score & Remark & Abbreviation \\
\hline 1. & Difference of 1 to 3 & No difference & ND \\
2. & Difference of $5-9$ & Trivial difference & TD \\
3. & Difference of 10 marks and above & Significant difference & SD \\
\hline
\end{tabular}

\section{Results and Discussions}

The result s of research questions are as presented in Table 2 to 4

Research Question One

What is the difference between post-test mean achievement of male students that learned financial accounting using peer-tutoring technique and those that adopts conventional technique in federal unity schools in north-eastern Nigeria?

Table 1: Descriptive statistics on difference between post-test mean achievement of financial accounting male students' in experimental and those in control group

\begin{tabular}{llllll}
\hline & $\mathrm{N}$ & Mean & Std. Dev & Mean difference & Decision \\
\hline Peer-tutoring & 14 & 66.68 & 11.62 & \multirow{2}{*}{12.47} & $*$ *SD \\
Conventional & 15 & 54.21 & 11.06 & & \\
\hline
\end{tabular}

*SD

The descriptive statistics presented in Table 4.2 revealed the mean scores of 66.68 and 54.21 for students in peer-tutoring and those in conventional method. The mean deviations stood at 11.62 and 11.06 respectively. The mean difference obtained was 12.47. Based on the analysis, it was concluded that there is significant difference between mean performance of male financial accounting students in experimental group and those in control group. The result is in favour of the experimental group. Research Question Two 
What is the difference between post-test mean achievement of female students that learned financial accounting using peer-tutoring technique and those that adopts conventional technique in federal unity schools in north-eastern Nigeria?

Table 2: Descriptive statistics on difference between post-test mean achievement of financial accounting female students' in experimental and those in control group

\begin{tabular}{llllll}
\hline & $\mathrm{N}$ & Mean & Std. Dev & Mean difference & Decision \\
\hline Peer-tutoring & 10 & 58.08 & 9.26 & \multirow{2}{*}{11.97} & $*$ SD \\
Conventional & 7 & 46.11 & 9.13 & & \\
\hline
\end{tabular}

*SD

The descriptive statistics used to answer research question three revealed the mean score of 58.08 with standard deviation of 9.26 for academic achievement of male financial accounting student in experimental group. Students in control group had mean score of 46.11 with standard deviation of 9.13. The mean difference obtained was 11.97 . The result therefore revealed significant difference (in favour of experimental group) exists between the mean performances of the two groups of students.

Research Hypothesis One

There is no significant difference between post-test mean achievement of students that learned financial accounting using peer-tutoring technique and those that adopts conventional technique in federal unity schools in north-eastern Nigeria?

Table 4: t-test analysis on difference between the mean performance of students taught financial accounting using peer-tutoring and those taught using conventional method.

\begin{tabular}{lllllll}
\hline & $\mathrm{N}$ & Mean & Std. Dev & Std. Error Mean & $\mathrm{t}$ & P-value \\
\hline Peer-tutoring & 24 & 65.64 & 5.43 & 1.086 & 23.57 & \multirow{2}{*}{000} \\
Conventional & 22 & 52.76 & 11.98 & 2.395 & & \\
\hline
\end{tabular}

The result of the data used to determine objective one shows the post-test mean score of 65.64 with standard deviation of 5.43 for experimental group. Students in control group had mean score of 52.76 with standard deviation of 11.98 . The $\mathrm{t}$-value obtained stood at 23.57 while the p-value was 0.000 . This value is less than alpha value $(0.000<.05)$, hence it was concluded that there is a statistically significant difference between the mean scores of the two groups of students. The hypothesis was not retained.

Discussion of findings

To determine the effectiveness of the peer tutoring teaching method on financial accounting students, three objectives were raised. The results were then collated to address the two of the research questions and one hypothesis. The results of the study show that peer tutoring method has positive effect on performance of financial accounting students. In the study, the students taught financial accounting using peer tutoring performed better than those taught using demonstration method. The result could be explained by the fact that peer tutoring strategy enabled students the opportunity to help each other to learn by addressing their individual differences. The students were thus challenged to figure out variables and relations that enabled them to solve accounting 
problems and open-ended problem in electricity concepts which hitherto was difficult to utilize and associate ideas to arrive at well-defined solutions.

This finding further affirmed many past studies which assert the effectiveness of peer tutoring on enhancing academic achievement of students. For instance the studies of Jason (2006), Maynard and Almarzouqi (2006) and Zakaria, Chin and Daud (2010) shows that peer tutoring academic attainment of both male and female students in skills subjects. Jibrin, Ibrahim and Zayum (2016) added that the adoption of peer tutoring teaching method in a class allows students to participate in the teaching and learning approach, share ideas, reduce anxiety and enhance students performance regardless of their gender. Strengthening these findings, the recent studies of Sahin (2010) and Joseph and Kabiru and Babayo (2012) reported that peer tutoring developed reasoning and critical thinking skills of student and their performance. Recently the study of Sam (2016) shows that peer tutoring strengthened and deepened understanding of the content of both the tutor and tutee which results in both academic and affective improvements.

Implications

From the conceptual perspective, the outcome of the study indicated effectiveness of peer tutoring teaching method on academic performance of accounting students. From a pedagogical standpoint, the finding revealed the adoption of peer tutoring teaching helps in motivating students, enhance classroom interaction, sharing knowledge and academic achievement of financial accounting students.

From the intervention standpoint, it becomes critical for accounting teachers to study the processes, strategy, classroom management, merits and demerits of the peer tutoring teaching method and develop strategies to overcome the challenges. Educational, given problem of demonstration instructional strategy that persistently erode the academic achievement of accounting students in both internal and external examinations, early detection and treatment would help to build strong foundation to accounting students, enhance their performance and retention.

Suggestions for future Study

The researchers suggested further study on "Effect of peer tutoring teaching method on working memory capacity of financial accounting students in Federal Unity Colleges, in North-Eastern Nigeria".

Conclusion

From the results obtained it was discovered that peer-tutoring is very effective instructional strategies of academic achievement and retention of students in financial accounting compare to the traditional method. It therefore means that using of peer tutoring teaching method will help to improve the current trend of dismal performance of secondary school students in financial accounting in North-eastern Nigeria. Hence it was recommended that financial accounting teachers should employ the use of peer tutoring teaching method in teaching financial accounting to secondary school students. In addition, students should be encouraged to actively participate in classroom activities. 


\section{REFERENCES}

Adamu, I., Bashir. A. U. \& Haruna J. A. (2015). Comparative Effects of Jigsaw Leaning Technique and Conventional Method on Academic Achievement and Retention of Ahmadu Bello University Students in Business Mathematics in Nigeria. Journal of Information, Education, Science and Technology (JIEST), 2(2).

Adamu, I., Haruna J. A. \& Bshir. A. U. (2013). Effects of Jigsaw and Lecture Based Techniques on Class Attendance, Participation and Proficiency of Undergraduate Students in Business Mathematics in Nigeria. Technical \& Vocational Education Journal. 5(1).

Anao, R. A. (2009). A Critical Appraisal of the Teaching and Practice of Accounting in Nigeria NASB SEMINAR FOR Accounting Teachers, Benin City 29 - 30 April.

Ani, K. G. (2007) Accounting Conventions and Accounting Concepts

Anowar H, and Rohani, A. T. (2013). Effects of cooperative learning on students' achievement and attitudes in secondary mathematics. 3rd World Conference on Learning, Teaching and Educational Leadership (WCLTA). Procedia - Social and Behavioral Sciences 93, 473 - 477 Baumann, J. F. (2004) Direct Instruction and reconsidering journal of Reading (31) 712 - 718. Ebel, R. L. \& Frisbie, D. A. (1986). Essentials of education measurement. Englewood Cliffs, NJ: Prentice Hall.

Ishaq A, M.(2011) Accounting In Nigerian Secondary Schools: A Case Study of Gombe State. Electronic Journal .

Jason, N. (2006). Thia undergraduate chemistry practical learning experiences using Jigsaw IV method. Journal of Sciences and Mathematics Education in Southeast Asia, 31(2), 178-200

Jibrin A. G..M, Ibrahim, A. And Zayum S .D. (2016) Effect Of Peer Tutoring On The Academic Achievements Of Upper Basic Students In Basic Science In Dengi Metropolis Of Plateau State. International Journal of Vocational and Technical Education Research, 2 (3), 25-35. From www.eajournals.org.

Kabiru, S. M. and Babayo, Y. A. (2012). Utilization of Resources for Effective Technical and Vocational Education and Training for Youth Employment in Bauchi State. Book of Proceedings NATT 25 ${ }^{\text {th }}$ Annual National Conference, Benue 2012.

Maynard, J. and I. Almarzouqi. (2006). Investigating peer tutoring. ELT Journal 60(1): 13-22. National Examination Council (NECO), (2004). Syllables and Examination Regulation for Senior Secondary School.

National Examinations Council (2013-2016) Nigeria Data Portal. From https://www.google.com.ng/search. Retrieved on 13/2/2017

Nuru, Y. A. (2008). NBTC Advocated Vocational and Technical Education for vision 2020. Daily Trust Newspaper. Thursday $24^{\text {th }} 2008, \mathrm{P} 2$.

Osuala, E. C. (2013). The mission of Business Education: Innovation of Vocational Education. Awka, Meths Publishers Limited.

Sahin, A. (2010). Effects of Jigsaw III technique on achievement in written expression. Asia Pacific Education Review, 12(3), 427- 435. http://dx.doi.org/10.1007/s12564-010-9135-8

Sam L. (2016). Gender Differences in Academic Performance of Financial secondary school students in Akwaibom state,Accounting Students in Selected Senior High Schools in the Central Region of Ghana. 
Tran V. D. (2014). The effects of cooperative learning on the academic achievement and knowledge retention, Int. J. of Higher Educ. 3(2), 131-140

West African Examination Council (WAEC), (2015). Chief Examiners Report: May/June West African Senior School Certificate Examination. Lagos: WAEC.

Wael, M. M. (2014). The Effect of Using Cooperative Learning Strategy on Graduate Students' Academic Performance and Gender Differences. Journal of Education and Practice, 5(11), 64 71. From www.iiste.org

Ward, P., Lee MA (2005). "Peer-assisted Learning in Physical Education: A Review of Theory and Research"J. Teach. Phys. Educ., 24: 205-225.

West African Examination Council (WASCE), (2016): Chief Examiners Report: May/June West African Senior School Certificate Examination. Lagos: WAEC.

Zakaria, E., Chin, L. C., \& Daud, Y. (2010). The Effects of Cooperative Learning on Students' Mathematics Achievement and Attitude toward Mathematics. Journal of Social Sciences, 6(2), 272-275. http://dx.doi.org/10.3844/jssp.2010.272.275 